DoI: http://dx.doi.org/10.11157/sites-vol11issiid246

- ARTICLE -

\title{
DEVELOPMENT THINGS:
}

A CASE OF CANNED MEAT

\author{
Philip Fountain
}

\begin{abstract}
Development scholarship in the social sciences has an awkward relationship with development things, often ignoring or sidelining materiality for analysis of cultures, discourses and power dynamics. Yet things are pivotal for how development works. This paper brings the anthropology of development into conversation with the burgeoning field of the anthropology of materiality. It focuses on a particular development thing: canned meat. The Mennonite Central Committee (MCC), a North American Christian NGO, has facilitated the production of canned meat for relief since the mid-1940s. Despite ideological shifts in conceptualising development, fluctuating financial constraints, changing hygiene regulations, arguments over labels, and the spectre of mad cow disease, canned meat remains a fixture in MCC's programmatic repertoire. Every winter 10,00o volunteers from rural Mennonite communities can a million pounds of meat for relief. In tracing the surprising voyages of canned meat to Indonesia I probe into how material things might be relocated as a vital area of research on development and in so doing open new lines of investigation. Specifically, and despite the apparent paradox, I propose that a focus on material things can help invigorate research into the emerging field of 'religion and development' by drawing attention to what can be called the theological life of things.
\end{abstract}

\section{INTRODUCTION}

Development scholars across the social sciences have an awkward relationship with the materiality of development. On the one hand there has been a longstanding tendency to thingify non-things. For example, development scholars frequently render development organisations as tangible, bounded objects but, as Hilhorst $(2003,3-5)$ has persuasively argued, 'NGOs are not things, but processes,' and rather than ask what an NGO is the more appropriate question 
concerns 'how "NGO-ing" is done.' On the other hand, the materiality of development has been sidelined for analysis of the cultures, discourses and power dynamics of development. The anthropology of development has likewise tended to elide materiality. ${ }^{1}$ Given that much development aims explicitly at material transformations, this inattention is peculiar. Things are central targets of development interventions and indispensable actors through which development is communicated, negotiated, mediated, enacted and contested. Things are not just incidental to development processes, they are constitutive of it.

In keeping with the general situation of neglect when I began my ethnographic research into 'religion and development ${ }^{2}$ I was largely uninterested in material development things. It was only during the course of my fieldwork, and this seems uncannily appropriate, that certain things compelled my attention. This paper takes up the task of tracing the 'social life' (Appadurai, 1988b) of a particular development thing: that of canned meat produced under the auspices of the Mennonite Central Committee (MCC), a North American Christian NGO, and shipped around the world for relief. Despite their historical neglect things are beginning to attract attention from other anthropologists of development. ${ }^{3}$ My argument draws on this emerging interest, and the wider burgeoning field of the anthropology of materiality, to argue that attention to material things provides invaluable openings for research in the anthropology of development. ${ }^{4}$

In their important proposal for an 'artefact-oriented anthropology' Henare and colleagues (2007b) convincingly argue for the productive value of 'thinking through things.' They advocate a heuristic approach to 'things' (a term that they find compelling because it is minimally freighted with theoretical baggage) in which an anthropologist engages with things 'as conduits for concept production.' This strategy assists in the creation of novel anthropological concepts while also eschewing the creation of a new meta-theory for addressing materiality. My approach to things is indebted to this prioritisation of methodology. The contribution of anthropology to the study of materiality is, as Miller (2005b, 14) argues elsewhere, an ethnographic immersion into the 'vulgarity' of commonsense apprehensions and mundane things. My purpose, accordingly, is less to establish a theory of things than it is to advocate for the cultivation of an ethnographic sensibility toward materiality in research on development, a sensibility which is attentive to 'richness, texture, and detail' (Ortner 1995, 174) and which creates space for a 'response' (Riles 2006b).

Yet my project on canned meat differs from Henare and colleagues' approach over questions of alterity. Embracing a 'radical constructivism' in which the du- 
alism separating the 'natural world and cultural difference' is denied, they argue instead that a 'plurality of ontologies' should replace commitment to a singular ontology (emphases in original). They propose that this maneuver enables them to take difference seriously. However, even if it is successful in doing so, it also serves to accentuate a sense of sharp, even rigid, boundaries of separation. Spurred by a desire to affirm radical difference they envision cultures as separated by chasms which cannot be crossed via translation. In contrast, and following Thomas (1991, 8), I suggest that alterity should be countered, if not displaced, by an emphasis on 'mutual engagement.' For this task, following things is instructive. My approach foregrounds the relational constitution of things, including via negotiations and contestations within particular communities and the reconstitution of things as they circulate across variegated cultural terrain. The process of tracing (contested, reconstituted) things necessarily includes examining how differences are bridged, crossed, diluted and/or reinforced, a perspective that militates against the kind of sharp alterity Henare and colleagues envision.

My approach to analysing relations and translations is to construct a 'biography' of the canned meat. In a seminal paper Kopytoff (1986) argues that the biographical study of things should attend to a thing's origin and its 'career', including different 'periods' navigated over the course of its lifespan. This facilitates attention to the 'moral economy' operating on things, including the way things are 'culturally redefined' as they move into new contexts. Unfortunately, Kopytoff is hamstrung by an overly sharp distinction between 'complex and highly monetized societies' and 'small-scale uncommercialized societies' and, consequently, a recurring emphasis on the differences between 'disparate societies' which, as per Henare and colleagues, presumes a radical alterity. In doing so, Kopytoff seems to ignore the way in which differences are created and reworked through these movements and interactions. As Rothman (2011, 4) argues, 'that two cultures are 'disparate' is not a pregiven fact but part of an ongoing process of boundary maintenance that unfolds in specific sites and institutions.' Rather than simply crossing over cultural boundaries, brokers and the things they mediate are actively involved in locating and renegotiating where the boundaries lie. Difference is not a static, rigid dividing wall; rather it is negotiated, contested and constituted through relational practices of mediation.

This biography of canned meat is presented as a case study of the differences, as well as the commonalities, that things mediate. In tracing canned careers I examine the distinctively Mennonite modalities of relief and service that are invested in them, including contestations over these modalities, as well as the 
ways in which the cans circulate in wider cultural fields. But my interest is not just in the valuations given to the cans. As a consequence of extensive histories of 'relationships, events, and interactions' (Taves \& Bender 2012, 11) the cans have been shaped by particular values and, in turn, inform those values. A can is not only endowed with meaning but it also 'makes possible or inhibits new practices, habits, and intentions' such that the 'causal relations' are reciprocal (Keane 2004, 193). The cans and the communities that produce and encounter them are related through a 'relay' effect (Gomart \& Hennion 1999).

As a consequence of these relational connections when things move they enter into new associations and help constitute new relationalities. Recent anthropological studies of 'commodity' or 'value chains' (West 2012; Lyon 2011), globalization and imperialism (Clifford 1997; Rothman 2012; Tsing 2005; van der Veer 2001), and development processes (Lewis \& Mosse 2006; Mosse 2005; Olivier de Sardan 2005; Rottenburg 2009) helpfully elucidate the generative and interactive dynamics of cultural meetings. These processes of cultural translation are characterised by an enduring ambivalence (Cronin 2000). Translation implies continuity and discontinuity, connection and disconnection, association and dissociation, transfer and transformation. Translation is therefore always already latent with the possibility of radical reconfiguration. The gap between decontextualisation and recontextualisation (Hull 2012), and the work required to carry something over (Bhabha 1994) to different contexts, is laden with transformative potential. As things move into new webs of relationships they are reconstituted, but without necessarily discarding the residue of past constitutions. For Latour, this transformative potential derives from the fact that every actor - regardless of whether this is a person or a thing - is a mediator, rather than a mere intermediary, which intervenes and is endowed with agency (Latour 1996; 1999; 2005). The theme of translation is, therefore, not so much an answer, but rather a question: How do things move across time and space? In order to answer this question it is necessary to trace the circuitous movements of things through multi-sited analysis (Marcus 1995).

In tracing the relationalities of canned meat, including their circulation within differing relationships, I pay particularly close attention to what might be called, with apologies to Appadurai, the theological life of things. This attention stems from my interest, noted above, in 'religion and development.' While focusing on the materiality of development may seem contrary, even paradoxical, to this concern with 'religion,' I argue in fact that paying close attention to material things provides valuable in-roads into the subject. Meyer and Houtman (2012) argue that while religion and things have long been 'conceived in antagonistic terms' this opposition needs to be countered as premised on a 
particular historically situated imagination. This imagination is, they suggest, a 'Protestant legacy' which locates matter as secondary and signification as primary, a dualism sustained by definitions of religion as concerned with 'spiritual beings,' 'beliefs' and 'interiority.' Yet, 'even Protestantism, which is usually taken to be an iconophobic and antimaterial religion, proves to attribute considerable importance to material stuff'. Accordingly, materiality and religion should not be seen as contradictory but rather as intimately related. Moreover, I argue that attending to material things opens new possibilities for the study of religion, including research into 'religion and development.' This is not only because, as Bautista and Reid $(2012,1)$ have argued, 'materiality is crucial to the very formation, enactment, and maintenance of religious belief,' but also because focusing on material things can help overcome the pervasive theoretical boundaries and epistemic categories that arbitrarily demarcate (and imprison) social science disciplines and sub-disciplines from each other.

By deploying the notion of 'theology' and by invoking 'religion' I do not mean to imply an ahistorical or transcultural conceptualisation of religion as an apparently distinct domain from the secular. Following Asad (1993; 2003) I regard generic conceptualisations as inhibiting the study of specific religious and secular traditions. Instead, in addressing 'theological things' I examine the ways in which canned meat is construed as endowed with (shifting) theological meanings and the ways it feeds into the theological life of particular communities. My attention to the theological life of things includes examining processes of theological articulation, translation, negotiation and contestation.

This paper is based on 22 months of ethnographic research between 2007 and 2008 on how the Mennonite Central Committee carries out its work, primarily in Central Java, Indonesia. While in Indonesia I never once came across an actual can of MCC meat. This is not especially surprising as material things are located in some places and not others and Central Java had not been a destination for canned meat for decades. While I eventually held an actual can at the Ephrata Material Resource Center in Lancaster County, Pennsylvania, during my three months of fieldwork in the (North American) summer of 2008, this lack of material presence in my primary field site meant that my physical encounters with canned things were limited. Nevertheless, the cans were a recurring topic of conversation with MCCers with canned narratives including discussions of their production, mediation and distribution. These (juicy) discursive traces of canned meat were further supplemented by written accounts on canned meat specifically and on MCC more generally, including various forms of online accounts, journalistic descriptions, MCC's own multimedia publicity, archival records, and scholarly texts. ${ }^{5}$ My research 
methodology therefore was a blend of what Tsing $(2005, \mathrm{x})$ calls 'patchwork' ethnography and Gusterson's $(1997,116)$ 'polymorphous engagement' involving an eclectic array of methods drawing on 'a disparate array of sources in many different ways.'

\section{CANNED BEGINNINGS}

When the Mennonite Central Committee was created during a meeting in Indiana in 1920 canned meat was not part of its repertoire of activities. But many of the conditions that would later make canned meat an indispensable, and indeed virtually nonnegotiable, feature of MCC's programming were. My exploration of these conditions is primarily concerned with the social context of North American Mennonite society in the twentieth century, but I also locate these dynamics within the longue durée of Mennonite history.

Despite chronic fragmentation North American Mennonites in the 1920 s shared a strong sense of common identity grounded in history. The Mennonite-Anabaptist tradition emerged in sixteenth century western and northern Europe as part of the widespread socio-political ferment of the period. Rather than a coherent movement it is better understood as dispersed communities that coalesced around certain themes, including particularly nonviolence, believers' (adult) baptism and an emphasis on state-church separation. Another unifying feature was the common experience of persecution by both Protestant and Roman Catholic authorities that was inflicted on Mennonites in large part because of their theological commitments. This experience of persecution, coupled with a desire for 'separation, led to a ruralisation of the Mennonite movement and also provided the impetus for mass communal emigrations beginning in the eighteenth century West across the Atlantic to the 'New World' and also East to the Ukraine, then a part of Tsarist Russia (F. H. Epp 1974; MacMaster 1985; Urry 2006). Over time the Mennonite movement developed into a distinct 'ethno-religious tradition' (Bush 1998,5) or 'peoplehood,' a term that is widely used by Mennonites to describe the particular sense of Mennonite identity. ${ }^{6}$ The Mennonite peoplehood are often described colloquially in the US and Canada as 'Germanic,' 'ethnic' or 'cradle' Mennonites. Yet the meanings of 'Mennonite' and 'peoplehood' remain contested among the plethora of different Anabaptist groups, conferences and factions (Loewen 2008; Nolt 1999; Winland 1993).

In 1920 Mennonites in the Ukraine sent a four-member Studienkommission (study commission) as emissaries to their co-religionists in North America with an urgent plea for assistance. The situation in the 'Russian' Mennonite 
colonies was dire. Multiple, overlapping crises - including the 1917 Bolshevik Revolution which located Mennonites on the wrong side of the class divide, the First World War which saw the Plautdietsch-speaking Mennonites facing strident anti-German sentiment from their neighbours, fierce fighting between the Red and White armies which took place in Mennonite backyards, and the widespread turmoil and famine that accompanied the transition in Russian government ${ }^{7}$ - brought Mennonite prosperity in the Russian colonies to an abrupt halt and left them in a desperate state (Urry 2006, 137-142). North American Mennonites heard this news with considerable concern and compassion, but while there were numerous regional and denominational relief committees focused on practices of 'mutual aid' there was no overarching body capable of coordinating a response of the magnitude required. At the urging of the Studienkommission Mennonite church leaders and relief committee representatives gathered in Prairie Street Mennonite Church in Elkhart, Indiana to discuss what could be done. ${ }^{8}$ The result was the creation of a 'Mennonite Central Committee' as a temporary centralised mechanism to coordinate the diverse existing relief committees and provide an efficient channel of assistance to the 'household of faith' (Unruh 1952, 11). ${ }^{9}$ In time this morphed into a more permanent central committee. Crucial in this transformation was the circulation of an organisational myth which located MCC as the mediator that brought together diverse and distanced co-religionists and as an indispensable tool in delivering material salvation to desperate Mennonite kin. As a 'central' meeting point, MCC became the 'United Nations' of the Mennonite world (Urry 2006,12 ) with the celebration of 'Mennonite ecumenicity' (Marr 2003, 17) being its primary raison dêtre in North America. ${ }^{10}$

Another animating dynamic was distinctive emphases in Mennonite theology, including particularly the priority on corporeal enactment and a striking belief in Mennonite difference. Mennonite theology locates Christian commitment as something that should be visibly apparent because fidelity is a practice rather than merely 'belief.' The imperative to materialise faithfulness drew upon a 'sharply dualistic' two kingdom theology that imagined a clear separation between 'the church' and 'the world' (Nolt 1999, 486-488). Believers mark their difference through technologies of inscription such as distinctive clothing, spatially separated communities and the bodily performance of ethical norms. Historically, among the most important bodily performances of faith is the practice of martyrdom which can be seen as the preeminent enactment of Christianity. Suffering and death for the sake of the faith materialises and makes apparent (witnesses to) the strength of one's faith in Jesus. ${ }^{11}$ The popular designation 'Die Stillen im Lande' (Pl. The Quiet in the Land) conveys these multiple theological valences: a self-conscious emphasis on difference; the 
rural and separated nature of most Mennonite communities; and corporeal alternatives to violence, including costly life-giving performances of faithfulness.

The confluence of these theological, material and historical currents ensured that when Russian co-religionists requested assistance North American Mennonite leaders responded decisively and practically. The newly formed MCC shipped grain supplies to the Russian Mennonites as well as fifty Fordson tractors equipped with Oliver two-bottom ploughs. As with the future canned meat, those tractor things spoke of the rural communities which sent them. These gifts - at this point decidedly not commodities ${ }^{12}$ - enacted a particular theology of faithful practice in which the materiality of the gift was prominent. In narrating this origin story to me during my fieldwork MCCers in Indonesia pointed out that, in the beginning, participation in MCC took place through 'physical things' which remains an enduring mode of constituent involvement. But the gifts did more than establish a tradition of material gifting, they also performed Mennonite relationality and thereby constituted a transnational, diasporic Mennonite 'peoplehood'.

MCC canned meat itself was inaugurated in the 1940s, twenty years after the Fordsons had been shipped to the Ukraine. Canned meat was born out of the Mennonite experience of the Second World War. Being pacifist American Mennonites faced mass conscription with deep concern. Unlike during the First World War ${ }^{13}$ the US government allowed for an alternative service scheme for conscientious objectors (COs) and many Mennonites embraced this option. By choosing against conscription and for constructive acts of public service Mennonites enacted their peace convictions and pursued the 'moral equivalent of war' (Bush 1998, 78-79; Toews 1996, 157). The CO work camps were organised and funded primarily by the Historic Peace Churches, which along with the Mennonites included the Religious Society of Friends (Quakers) and the Church of the Brethren. In the Mennonite case MCC was the only inter-Mennonite organisation with the requisite administrative capabilities and broad constituent support to operate their camps. The disaster of war therefore gave MCC a new burst of life and renewed momentum for inter-Mennonite cooperation for peace and service, an irony not lost on some observers (Juhnke 1996).

Mennonite COs needed to be fed and otherwise supported and so Mennonite communities, primarily women, were tasked with providing them with foodstuffs, including bottled vegetables, fruit and meat. Bottling fresh produce for storage during long North American winters was a near-universal practice among Mennonites at that time and drew on domestic skills honed over gen- 
erations as well as readily available domestic accoutrements. The glass bottles were ideal for preserving (via sterilisation) foodstuffs through simple yet ingenious techniques of heating and sealing. The bottles enabled wide community participation in supporting the alternative service camps as their production required only readily available things and commonplace practices. They were, however, both fragile and heavy which greatly limited their transportability.

Immediately after the war American Mennonites engaged in relief and reconstruction work in Europe, again particularly among war-torn Russian and other European Mennonites (C. J. Dyck 1980b, 56). ${ }^{14}$ This reflected their fellow citizens' enthusiasm for the dawning of the new 'development' era (Cullather 2010; Ekbladh 2010; Rist 2002, 69-79) but also reflected specifically Mennonite concerns. Suffering from 'philanthropic guilt' due to buoyed war prices (Kniss 1997, 49), facing the demise of traditional markers of distinctiveness (such as plain clothing, rural separation and use of Plautdietsch), and spurred by new theological articulations which 'legitimated an outward missional activism' (Toews 1996, 84) Mennonites turned increasingly to practices of service to buttress their identity as 'a separate and identifiable people' (Bush 1998, 272). Using relief in Europe as an initial stepping stone MCC leaders launched programmes throughout the (newly-minted) 'underdeveloped' world (Unruh 1952; C. J. Dyck 198ob).

At this time rural Mennonites continued to gift things through MCC, including agricultural things (Marr 2003, 67-97). Extending the practices of support offered to COs, bottled foodstuffs were shipped to Europe. These attempts, however, proved entirely unsatisfactory. Glass travels poorly on the high seas and, according to one account, a quarter of these early shipments smashed en route (Relief Canning, Inc. 2013). Shattered glass bottles and wasted foodstuffs spurred interest in locating a more appropriate container thing. It was in this context that 'tin cans' were first explored as a possibility. Tin cans are cylindrical containers ('canisters') made out of thin tinplate steel (and later also aluminum), with the tin providing a non-corrosive layer for rust-prone steel. The practice of using tin cans for storing foodstuff was invented by French and English entrepreneurs in the early nineteenth century, initially in order to provide their respective navies with durable and easily transportable food while ships were out at sea (Shephard 2006, 226-255; Geoghegan 2013). The tin can was a 'packaging pioneer' (Busch 1981) invented specifically to cope with rough journeys. Canned foodstuffs equaled the longevity of food sealed in bottles but, in contrast to brittle glass, cans were more durable on account of the greater malleability of tinplate steel. The use of cans greatly expanded the geographic horizons for transportation. Canned foods became a regular 
feature in American diets in the 1870s, following a sharp increase in the production of canned food during the American Civil War. Canned meat was therefore already commonplace in the 1940 os as part of a broader expansion of 'large-scale capitalist provisioning' (cf. Errington, Fujikura, and Gewertz 2013). ${ }^{15}$

The disadvantage with canned meat was that while bottling could be done in any Mennonite kitchen, canning required particular machinery that was not so readily available. In 1946, working independently of each other, a Mennonite business in Virginia's Shenandoah Valley and a group of Mennonites in Hesston, Kansas built and operated portable canners to facilitate the processing of food for overseas relief. Though still rather clunky, these canners could be moved to wherever they were needed. The idea of a mobile meat canner was a creative practical response to rural Mennonite resources and new opportunities. Notably, MCC administrators did not initiate the canning process. MCC was, rather, the organisation in which the meat canner came to be housed. This mobile apparatus for packaging foodstuffs effectively produced a suitably tenacious container and facilitated diffuse communal participation. The idea - and the thing itself - took off. The Kansas canner was formally donated to MCC in 1952 to make it available to a wider cross-section of Mennonites. This canner remained in active service until its replacement in 1973. Two decades later the second canner was succeeded by one that still operates today. The current 'cannery-on-wheels' (Jurgelski 2010) is mounted on a 42 -foot long flat-bed trailer. The trailer's fold-up sides make it both alternatively enclosable (for transportation or during the off-season) and accessible (during canning) as needed.

As this brief history of the origins of canned meat illustrates, the thing of MCC canned meat was not incidental though nor was it inevitable. Rather canned meat emerged at a particular juncture due to a specific confluence of factors. Canned meat and the material gifts that preceded it were relationally-formed within Mennonite communities and served to bolster, and even helped establish, those communities.

\section{CANNED PRODUCTIONS}

For most of its history MCC's mobile canner produced about $95 \%$ canned beef. However, since the sharp increase of incidences of mad cow disease (bovine spongiform encephalopathy, $B S E$ ) in the early 200os, and particularly due to BSE's extensive mediatisation, the canner switched to turkey, though it still does some beef as well as chicken and pork. An MCC worker told me that this shift in the type of meat used by the canner inflated the cost of turkey 
in the US from forty-five cents to over one dollar a pound. The canner can process 9,000 pounds (over 4000 kilograms) of chunked turkey thigh per day. In this section I draw on a textual and an audio-visual account to examine the production of canned meat.

Between October and May each year the meat canner follows a set route with thirty-four stopovers in thirteen US states and two Canadian provinces. In the wittily titled Together We Can, Wanda Yoder's (2010) self-published account of her seven-month 12,000-mile journey accompanying the meat canner, we are given a rich first-hand narrative of a canning season circuit. The canner's path is a cartographic roll call of Mennonite and Amish heartlands. While a fourperson skeleton crew accompanies the canner on its route most of the work is carried out by local, autonomously-organised communities. These volunteers are largely rural and inclined toward the conservative end of the Mennonite mosaic. Almost everyone Yoder mentions in her account have identifiably Mennonite family names: Friesen, Brenneman, Redekop, Dyck, Stolzfus, Burkholder, Showalter and so on. In these encounters Yoder - itself a prominent Swiss German Mennonite surname - celebrates the 'shared bond' she feels exists within and across Mennonite communities.

Yoder's experience is movingly narrated as 'overwhelming, wonderful.' Particular attention is given in her account to matters of generosity, care and hospitality. These acts of benevolent service include both that which is shown to her by host communities and also their exhibitions of kindness in volunteering and donating that make the canning possible: 'These are such great people who volunteer their effort to benefit others who are mostly unknown strangers.' In summarising the canning process as providing 'a tangible opportunity [for people] to share their time and money to benefit other people who need assistance, Yoder draws a clear distinction between generous givers and needy recipients. Yoder's own experience of the 'romance of service' was perceived to be a great privilege, even though - or rather, precisely because - the hard work, frigid weather, and extended absence from home involved considerable personal sacrifice.

Insights into the canning itself can be gleaned by viewing a promotional DVD entitled 'Manna from Heaven', the first of the two-part Taming Hunger series (Mennonite Central Committee 2007a). The video focuses on the production of canned meat in Winkler, Manitoba. It is clearly a visceral and sensorial process. Canning involves active, even vigorous, work that transforms raw meat into a packaged product ready for global travel. Men wearing white butcher jackets, hardhats and earmuffs trundle around cramped spaces with trolleys 
of caged cans; carcasses of meat hang by metal hooks awaiting deboning and grounding; men with hair and beard nets stir meat chunks with large clubs while broth stews in huge vats. Always there is hissing, the source of which is eventually revealed as white columns of steam escape from giant pressure cookers. The backdrop is sterile, clinical, modern: stainless steel shelves, white walls and industrial-sized machinery. After the meat is canned, cooked and then cooled, women (wearing the same white butcher jackets and hair nets or head coverings) clean the cans in large tubs of soapy water and then send them on to be labelled and glued. Finally, the cans are packed neatly away in boxes. The images of volunteers accentuate the corporeality of canning-as-gifting. Rather than a mundane and bloodless cash donation, canning is immersive and intense. The physicality of the labour, the heat of the steam and the chill of winter, the smells, the dress codes, the physical locatedness of each volunteer as filling a particular task within a well-oiled production chain are all deeply effective and affective modes of embodiment. The olfactory, auricular, ocular and tactile (though notably not alimentary, as consumption was intended for others) nature of meat canning embroils each volunteer in a profound, intense experience.

The camera repeatedly focuses on the image of the can itself, the label of which, in a simple, minimalist black-and-white aesthetic, displays MCC's logo with the words 'FOOD for RELIEF' and 'In the name of Christ' (See Figure 1). ${ }^{16}$ At one point Don Peters, the Executive Director of MCC Canada, tells viewers that through the canning, 'MCC is sending a message, 'service in the name of Christ,' MCC is sending the message to people wherever they are going to receive these cans that people in Canada and the United States care about them.' The male narrator reinforces the theme: 'Hungry people all over the world now know the love of Christ thanks to the dedication of hard-working volunteers, the generosity of the people and organisations donating meat and

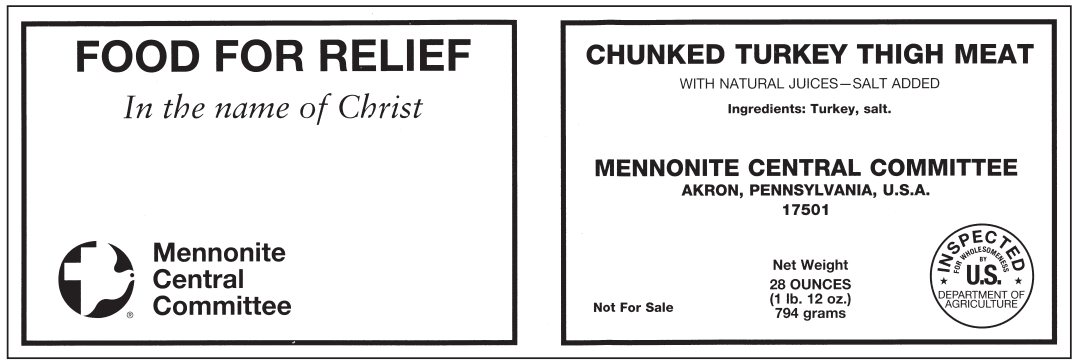

Figure 1: The Label (used with permission) 
money, the committees who work tirelessly day and night to pull it all together.' The cans imbue Christian faith - they contain not only nutritional value but also a theological message.

The documentary closes with images from North Korea, Guatemala, Iraq, and Bosnia illustrating the globe-trotting journeys that await the cans. Africans are shown sitting outside a rustic home happily consuming the canned meat during a family meal. Others - perhaps Iraqis - reach out for it during distribution so they can add it to their bags of emergency provisions. Another MCC Canada staff member narrates this transnational ambit with a story from an unnamed foreign country: 'And it was an orphanage in which they were giving, I think, one can of meat to about fifteen young kids and the woman who was the head of the orphanage said to one of the MCC people, "Don't you ever think about not doing this because this is about the only protein these kids get." This articulation of a moral imperative for continuing canning relies on both its past valuation and its imagined ongoing worth. As with Wanda Yoder's descriptions, canned meat is a tangible service to help others in need.

Further discussion of three key features - the meat, the label and communal dynamics - raised by these accounts deepens our investigation into the production of canned meat.

In a vivid account of abattoirs in South West France, Vialles (1994) interrogates the deceptively simple question 'what is meat?' via an ethnographic analysis of the operations that transform animals into edibles. The central moment of transformation takes place at the 'slaughterhall' in which living, dirty animals are immobilised, stunned, hung, bled, flayed, eviscerated, split and weighed before being moved into a refrigerated, sterile area. This process involves 'stripping the animal of its animality.' While in pre-revolutionary France this took place alongside the road it was 'exiled' to rurally-located abattoirs due to growing distaste over the act of killing animals and also because of increasing regulations imposed by the modern state seeking to ensure 'humane' treatment, hygiene and consistent standards. These insights are pertinent for thinking through MCC's canned poultry. While MCC discourses about canned meat focus on life-giving nourishment for recipients, the unavoidable fact is that it relies on the slaughter of animals. The turkey meat is sourced through big business supply chains ${ }^{17}$ which separate the killing from the canning. This demarcation is not strict, however, as at some sites the canner is attached to 'meat processing plants.' Furthermore, a few decades ago this disconnect was considerably less pronounced as Mennonite farmers were frequently both canning volunteers and the donors of the cows that were canned. These ambiguities 
speak to enduring rural Mennonite sensibilities and particularly the ongoing lived proximity connecting food production and consumption. Another connection with Vialles' account is the influence of state regulation on MCC canning. MCC publicity frequently emphasises the compliance of canning with the stringent standards established by both the Canadian Food Inspection Agency (CFIA) and United States Department of Agriculture (USDA). The force of modern political-legal requirements is made most apparent in the tangible, physical presence of food inspectors, and considerable effort is devoted to ensuring that food inspections go smoothly. ${ }^{18}$

The fact that the canning involves cooked meat is also noteworthy. Cooking, as Lévi-Strauss (1966) pointed out a half-century ago, is a 'cultural transformation of the raw' which renders meat amenable for consumption. The cooking of the canned meat is via boiling which, for Lévi-Strauss' structuralist analysis, is the most 'cultural' and least 'natural' point in the culinary triangle. The eating of cooked meat has, according to Gewertz and Errington (2010, 16-17), historically been a small proportion of the human diet and, in part because of this, eating meat is widely regarded as 'special' and closely associated with 'wealth and privilege.' Indeed, more than just nourishment canned meat is decidedly special. ${ }^{19}$ Mennonites canned meat narratives frequently reiterate that the food shipped out to the 'hungry' and 'needy' is both tasty and nutritious enough to be served on the tables of those who produce it.

That this cooked meat was a special gift is directly connected with theological dynamics operating in and through the canning. These dynamics are inscribed on the can label (again, see Figure 1). Importantly, the theological relationship between the canning, the canners and the label is a dynamic one. The phrase 'In the Name of Christ' bathes the cans in a sacred aura and sanctifies the canning process. Because 'service' is a Mennonite sacrament (Burkholder 2010), the acts of voluntarism, generosity and self-giving involved in canned productions likewise sacralise the cans and the canning. Also, for at least some canners, the entire process is seen as divinely instituted. ${ }^{20}$ The profoundly corporeal experience of canning, furthermore, is what philosopher-theologian James Smith (2009; 2013) would call an immersive 'liturgy of desire' which expresses worship and simultaneously shapes theological formation through an affective pedagogy. The liturgical character of canning is also apparent in the repeated textual refrain 'In the Name of Christ', which operates something like a Mennonite rosary.

This sacral dynamic is narrated by Wanda Yoder $(2010,59)$ in her description of a 'blessing of the cans' which took place in Spartansburg, Pennsylvania during 
which one Enos Troyer from the Greenville Amish Church led volunteers in a group prayer over the products of their labour. This 'very important part of the canner ritual' has a distinctly Eucharistic tone. So too does the third appendix in Yoder's book, originally written by an unknown author and entitled 'I am a Can of MCC Beef' (2010, 108-109). This ludic autobiography presents the story of canned meat from the can's point of view. Its production by 'Christian people' and its shipment to 'one of the world's hunger spots' is eventually concluded with distribution (accompanied by children jumping for joy, tears and much 'jabbering'): 'The family that took me home is bowing their heads to thank God for the meat I brought to them. There really is a special reverence around this table. Why don't you join them in asking God's blessing on this special meal.'

The ritual of producing canned meat is a deeply communal affair. Indeed, in contrast to ordinary industrial canning, the production of MCC canned meat centres on the effervescence of communality. Canning brings communities together to accomplish a task focused on others. This external orientation both deflects attention from internal differences and provides a raison dêtre which many Mennonites can affirm as worthwhile. Through the practice of canning meat, therefore, Mennonite community dynamics are re-shaped, including perpetuating a sense of the distinctiveness of being Mennonite. Yet the communities that participate in this annual canning ritual don't merely attend an MCC event, rather they own the process in their town. Autonomous, locallyorganised committees are responsible for purchasing the meat and arranging for facilities, fundraising and volunteers. These committees collectively organise over 10,000 volunteers each year to operate the canner for long hours over multiple shifts and on the basis of boot-camp discipline.

The deep commitment to canned meat was forcefully expressed during a conversation I had with a conservative Mennonite leader at the Hinton Relief Center in Virginia. At the time MCC was considering changing the label because of problems encountered in the field (I address these dynamics below). Indeed, a few weeks prior to this conversation I attended MCC's Annual General Meeting in Kitchener, Ontario during the course of which a 'break-out session' heard a report on an organisation-wide review of material resources which floated the idea of switching 'In the Name of Christ' to a more innocuous phrase such as 'A Christian Resource for Meeting Human Need.' When I asked my Hinton host what he thought about this proposal his reply, intended at least as much for the MCCer who accompanied me, was conspicuously direct: 'If MCC changes the label, I stop canning tomorrow; the whole of Virginia stops canning tomorrow. 'In the name of Christ' was not up for negotiation. 'That pile of meat is a small drop, but that's our drop' he told me. 
But MCC's constituency doesn't only consist of passionate meat canners. The cans have plenty of Mennonite critics. Vegetarian and vegan donors find the practice distasteful. Many Muppies ${ }^{21}$ consider it antiquated. Some professional Mennonite development workers familiar with community development discourses of 'participation' and 'empowerment' see the dolling out of canned meat as dependency-inducing. Former MCCer Will Braun (2005), writing in Canadian Mennonite magazine, argues that the 'buckets and blankets' approach - a short hand for MCC's material resources programmes of which canned meat is a part - fails to engage constituents in the politics of global socio-economic inequality and instead gets 'bogged down in an us-helping-them framework.' Rather than addressing underlying socio-economic inequalities, canned meat serves to placate Mennonite consciences through encouraging participation in feel-good practices. Braun rejects merely offering 'help' and instead pleads for a reorientation toward 'redeem [ing] broken economic relationships', a task that is framed as normative for Christian communities. Braun calls on MCC to facilitate these transformations among North American Mennonites by engaging in proactive, political conscientisation. In Braun's critique the cans are disenchanted and desacralised and an alternative theology of service is endorsed.

Because MCC's donor constituents don't share a coherent theology of service inconsistencies and conflicts are pervasive. Canned meat is simultaneously sacralised and disparaged, fetishised and disowned, promoted and critiqued. These contestations among Mennonites over the canned meat highlight the ways in which canning, including its communal and theological dynamics, is complex and continually under negotiation. While the canning volunteers work hard to produce a single standard object, the theologies informing the cans are multiple.

\section{CANNED JOURNEYS}

The mechanisms that make meat canning possible, if also deeply contested, operate autonomously from the mechanisms of distribution around the world. The practice of shipping canned meat involves translation. This ambivalent process is laden with transformative potential as well as the possibility of continuities. The following two brief examples of canned meat journeys illustrate these potentialities. Rather than a comprehensive analysis of their global circulation - which in any case is an impossible task given the prolific and diverse nature of these journeys - these narratives intimate toward the processes involved in their travels. ${ }^{22}$

In the wake of the Second Iraq War MCC shipped large quantities of cans 
into Iraq. I was told by a senior MCC administrator that when these cans were transferred to a local partner for distribution, the partner was appalled. In the complex and fraught politics of occupied Iraq - replete with religious tensions and ongoing frequent violence - the distribution of cans that boldly proclaimed 'In the Name of Christ' seemed to the local partner to be foolhardy and inflammatory. This reading of the label should not necessarily be viewed as a misunderstanding resulting from (mis)translation. Instead, it seems equally plausible that the label was read in much the same way as (at least some of) the producers had read it: as an inscription of Christian sacralisation. Rather than a misinterpretation what the partner found concerning was sharply juxtaposed evaluations. In a context where (Sunni and Shia) Islam is adhered to by the vast majority of Iraqis, the valuation of Christian sacralisation was likely to be less highly esteemed than it had been among Mennonite canners. Yet, the can and the meat were still considered beneficial in the post-war context of food shortages. The cans, therefore, continued to elicit willing support from the local partner even as the label was rejected. Caught between the impossibility of 'that's our drop' and an instigation of violence the partner took one of the few remaining options: the labels were torn off prior to distribution. In this journey, the label was martyred so that the cans and the nourishing meat could proceed unscathed.

Another tale of canned meat concerns its travels to Indonesia. In early 2007 an MCC staff member in Akron, Pennsylvania initiated plans to ship cans to Aceh, the province that had been devastated by the massive December 2004 Indian Ocean earthquake and tsunami. ${ }^{23}$ His task was to locate destinations for shipments. The production of the cans took place on an annual cycle, propelled by dynamics divorced from the (fluctuating) needs of specific recipient communities. The MCC staff member's job was to dissolve a generic 'needy' other and replace it with specific communities of consumers in actual (geo-political, geographical) localities. To do this, the canned meat had to navigate its way through the convoluted politics of access. Given that it was over two years after the tsunami had wrecked devastation, MCC staff in Indonesia were dubious about whether the distribution of canned meat was really an appropriate intervention. Some thought that long-term initiatives, such as offering training in sustainable agriculture, would better facilitate food security than dispersing large quantities of chunked turkey. But the Akron-based MCCer was persistent and so Indonesia-based MCCers sought meetings with the appropriate Indonesian officials to try to arrange the shipment. These discussions met a brick wall with two issues being particularly intransigent.

First, paralleling the Iraq example, the label's explicit Christianity as entex- 
tualised in the phrase 'In the Name of Christ' was considered inflammatory. Aceh is almost entirely Muslim and is widely considered in Indonesia to be an especially pious region, a fact that is acknowledged in the common slogan of Aceh as the 'Veranda of Mecca.' Government officials were consequently sensitive to charges of kristenisasi (In. Christian evangelism) and it was thought that the label would be read as an act of proselytisation. Second, the canned meat was not halal (Ar. lawful, permitted). In his important account of The Halal Frontier Fischer (2011) explores the contested and changing conceptualisation of halal among the contemporary Malay Muslim diaspora. He points to the increasing significance of halal practices during the twentieth century and especially since a major food scandal in Indonesia in 2001 triggered a new phase of halal proliferation. The issue at stake in the food scandal concerned accusations that a Japanese company was using pork-derived products in the production of (widely used flavour enhancer) monosodium glutamate (MSG). The consumption of pork is explicitly declared haram (Ar. unlawful, forbidden) in the Quran. The fact that the MCC mobile canner equipment is used not only for turkey but also for pork meat places the entire production under question in the context of the ever-intensifying demands for the Islamically proper in consumption.' Another key feature of halal food is the requirement that animals, including poultry, be ritually slaughtered (Ar. dhabh). This involves the invocation of God's name at the moment in which a fatal incision is made across the animal's throat and letting the blood of the animal drain as much as is possible. ${ }^{24}$ The lack of dhabh practices for the slaughter of the turkeys, and the use of 'In the Name of Christ' on the label (rather than Allah, for example), constituted an insurmountable problem for the government officials. Faced with an unambiguous rebuff, and reinforced by their own ambivalence, MCC Indonesia staff called off the attempt to ship canned meat into Aceh.

But the story did not end there. The Akron-based administrator was not convinced that all avenues had been pursued. He doggedly continued to try to fulfil his mandate of getting the meat out. Bureaucratic concerns and collegial indifference were obstacles to be traversed rather than merely accepted. He consequently bypassed MCC staff in Indonesia and located another organisation, Tsunami Earthquake American Relief Services (TEARS), who agreed to try to arrange the shipment and distribute the cans. TEARS was formed in January 2005 by the Lake Jackson Church of Christ in Texas ${ }^{25}$ in response to the tsunami catastrophe. It worked in South Nias, initially largely in the form of short term medical missions of American volunteers. Unlike MCC Indonesia, this organisation had explicit evangelistic goals. Nias is an island off the coast of Sumatra which was also affected by the tsunami (and again by the 8.7 magnitude earthquake of March 2005), though less severely than other parts 
of coastal Sumatra. The population of Nias predominantly identifies as Protestant Christian. TEARS arranged to have the cans pass through Indonesian customs on the basis that the cans would only be distributed in Nias. The cans got through in this instance with the labels still on, though the labels as well as the meat continued to shape their (convoluted) circulations. MCC's canned meat in Indonesia was therefore distributed along an entirely Christian route: produced by Mennonite donors, facilitated by MCC administrators, delivered through a mission agency, and consumed by a Christian populace. Here, therefore, a certain 'similarity' greased the cogs of transmission. Intransigent in some contexts, canned meat flowed much more easily into others. Clearly, the theological life of canned meat as it circulates globally is continually negotiated and contested, with sometimes quite unexpected outcomes.

\section{CONCLUSION}

The exploration of the webs of relationships surrounding the origins, production and distribution of the thing of canned meat facilitates analysis of key dynamics operating within and upon the Mennonite Central Committee. The biography of canned meat furnishes an understanding of development-inaction as dynamic, contested and mediated. Their movements along precarious and turbulent routes are all the more engaging for the fact that 563,648 cans experienced them in 2009 alone (Jurgelski 2010).

This paper provided a detailed, textured ethnographic narrative of a particular development thing in order to illustrate the value of paying attention to materiality in the anthropology of development. As is apparent in the above narratives a key insight to be gleaned from following these canned things is the ways in which they embroil an extraordinarily diverse range of other things and processes: transnational Mennonite identities, Bolshevik revolutions, industrially-produced turkey meat, mad cow disease, the Canadian Food Inspection Agency, war-time economic booms for American agriculture, European inventors, Mennonite theologies of the gift and rituals of service, Islamic theologies of purity and pollution, partner anticipations, recipient tastes, warfare and tsunamis, and many more were implicated in shaping the creation and circulation of canned meat for relief. This insight, or rather the canned thing itself mediated through this insight, does at least two things for the anthropology of development.

First, the study of development must avoid becoming enclosed in a hermetically-sealed disciplinary canister. The anthropology of development must give attention to a wide array of factors precisely because they impact the way 
development actually takes place. A focus on development narrowly conceived is disadvantageous because it cuts off attention to these wider dynamics. The required broad purview includes exploring the logics and practices of donors and recipients, as well as the brokers that mediate between them.

Second, and this returns to the discussion of 'religion and development', the theological life of canned meat shows that tired dichotomies separating materiality from religion should be discarded. While these distinctions have been critiqued by specialists in material culture, scholars working on 'religion and development' have hardly begun to take account of things. An anthropology of development that follows the circulation of things will also be one that gives attention to the material mediation of theology as it is encountered (or, just as interestingly, not encountered) in different contexts. Attention to materiality by anthropologists of development therefore promises new, productive openings in the emerging research agenda on the intersections of religion and development/humanitarianism. ${ }^{26}$ While there is a pressing need for investigating specific religious traditions, and specific sacred things, anthropologists must do more than examine local cultures and their diverse perspectives and religions. We must also explore the circulations, translations and transformations that take place as development things circulate around the world.

\section{ACKNOWLEDGEMENTS}

I am grateful to Dhiman Das, Phil Enns, Lorena Gibson, Gillian Lê, Victor Sensenig and two anonymous reviewers for their helpful comments in revising this paper. An earlier version was presented at the Association of Social Anthropologists of Aotearoa/New Zealand (ASAA/NZ) Conference, Wellington, New Zealand in December 2012. Fieldwork was made possible by generous grants from the Australian National University and the Religious Research Association's Constant H. Jacquet Award. Throughout my fieldwork Mennonite Central Committee personnel were remarkable hosts and generous friends. I am thankful for both gifts. Thanks also to John Hillegass, the MCC Canning Coordinator, who kindly mailed canned meat labels to me and allowed for their use in this paper.

NOTES

1 This is apparent, for example, in that neither Fisher's (1997) nor Mosse's (2013) thorough reviews of the anthropological literature on NGOs and development, respectively, include significant discussion about materiality, though the latter does address the theme in passing. Many of the 'classics' in the anthropology of 
development, such as Escobar's (1995) seminal analysis of discourses of development, give little attention to materiality. Even Mosse's (2005) outstanding ethnography of a development aid chain, which draws explicitly on a Latour-inspired actor network approach, pays limited attention to materiality. Some exceptions are addressed in note 3 below.

2 This long-neglected field, indeed for a long time a veritable 'taboo' (Ver Beek 200o), has recently gained considerable momentum. Yet much of this literature remains 'instrumental, narrow and normative' (Jones and Petersen 2011) and the conceptualisation of religion is frequently of a generic, sui generis type critiqued by Asad (1993) and Cavanaugh (2009), among others, as ignoring the historicity of the concept and its ideological baggage (Fountain 2013). Recent ground-breaking anthropological studies are, however, moving the field forward. See particularly Benthall and Bellion-Jourdan (2009), Bornstein (2003; 2012), Fountain (2011), Hefferan (2007), Huang (2009), Nadeau (2002), Occhipinti (2005) and Rudnyckyj (2010).

3 See particularly Riles' (2000) attention to the 'aesthetics of artifacts' among NGO activists in Fiji, Ferguson's (1999) analysis of the material performance of 'localist' and 'cosmopolitan' styles on the Zambian Copperbelt, Redfield's (2013) attention to the workings of material objects in the practices of Doctors Without Borders, and Hull (2012) and Gupta's (2012) sophisticated studies of the materiality of bureaucracy in South Asia. See also Korf and colleagues (2010) for an insightful biographical study of the gift in a disaster relief context.

4 As this indicates my argument is primarily concerned with the anthropology of development as a sub-discipline within social anthropology. For impressive forays into the anthropology of materiality, which compellingly establish the study of material things as a key field of anthropological concern, see particularly the edited collections by Appadurai (1988a), Henare, Holbraad and Wastell (2007a), Miller (2005a) and Riles (2006a).

5 For brief histories of meat canning see the dedicated website provided by the Mennonite Central Committee (2007; nd.) and also W. L. Yoder (2010). For the rich scholarly literature on MCC see particularly Dula and Epp Weaver (2007), Epp Weaver, (2011), Fountain (2011), Graber Miller (1996), Jantzi (2000), Kreider and Goossen (1988), Kreider and Mathies (1996), Marr (2003), Sampson and Lederach (2000), Welty (2010), and R. A. Yoder, Redekop, and Jantzi (2004).

6 For Urry $(2006,6)$ the notion of peoplehood indicates: 
the particular Mennonite sense of identity based on their faith and sense of being and belonging. Core features of what it means to be a people of faith are often expressed in their confessions of faith and include adult baptism, nonresistance, and remaining separated from 'the world'.... Belonging is centred on a strong sense of social community founded on the interconnections of people through descent, both from founding ancestors and the historical experiences of the people of faith and often also through the genealogical descent of the community's members. The popular concept of 'ethnicity' does not quite capture this sense of being and belonging, which is informed by a culture of faith rather than faith in culture.

Distinctive practices have included wearing 'plain' clothing, culinary practices, and the use of Plautdietsch (Low German) with other Mennonites and High German in church services, though these have been substantively reworked particularly since the Second World War.

7 Between 1921-1922 approximately nine million people died across the Soviet Union in one of the largest famines of the twentieth century (Reimer and Guenther 2011,355).

8 This rather innocuous beginning has been much discussed, debated and mythologised (C. J. Dyck 1980a, 1, 9-22; Hershberger 1970; Unruh 1952, 12-16; Juhnke 2011).

9 Though supported by many Canadian Mennonites, at its founding MCC was considered an American organisation (E. R. Epp 1980, 23). MCC's links with Canadian Mennonites greatly strengthened during World War Two, though it was only in the 1950 and 1960 s that MCC would move toward becoming a Canadian, and therefore also a binational, agency (E. R. Epp 1980; F. H. Epp 1983; Epp-Tiessen 2011; Marr 2003).

10 Numerous accounts of MCC return to this theme (Bush 1998, 29; Driedger and Kraybill 1994, 70; Kehler 1970, 298).

11 Widely circulating martyrologies account in graphic detail the persecution faced by early Mennonites. See particularly Van Braght's (2002 [1660], 741-742) Martelaarspiegel or Martyrs Mirror.

12 Appadurai (2006) rightly notes that the distinction between 'gifts' and 'commodities' is neither rigid nor enduring such that 'today's gift is tomorrow's commod- 
ity. See also Ellen and Platten $(2011,581)$ and Thomas $(1991,28)$. While both the grain and Fordsons might have been purchased as commodities, their donation to Russian co-religionists via MCC transformed them into gift. Whether they were received this way or whether they were later re-translated into commodity after reception was, however, indeterminable at the moment of donation.

13 This was a particularly bitter period for many American Mennonite communities (Bush 1998, 27-32).

14 The role that MCC played in the 'exodus' of Mennonite refugees escaping from Germany immediately after the war has been told repeatedly in Mennonite literature and oral storytelling (P. Dyck and Dyck 1991; C. W. Redekop 1980; Regehr 1991; Smucker 2006; Unruh 1952, 24-39, 175-226).

15 Notwithstanding the 'distinct' nature of instant noodles, as proposed by Errington and colleagues (2013) in their fascinating The Noodle Narratives, the comparison between canned food and instant noodles is revealing. Both are 'tasty, convenient, cheap and shelf stable' and also, relatedly, 'inexpensive and widespread... familiar and acceptable.' These characteristics have, perhaps unsurprisingly, led to instant noodles also being deployed for the purposes of relief:

WINA [World Instant Noodles Association] donated 550,000 packages [of instant noodles] to quake-hit China on June 23, 2010, and 10,000 packages to flood-stricken Hungary on May 28, 2010. Similarly, during 2011, Nissin Foods donated one million servings to tsunamiravaged Japan along with seven 'kitchen cars', each capable of serving about eighteen hundred cups of noodles daily even where water and power supplies had been interrupted (2).

During the Surakarta flooding in Central Java in December 2007 and January 2008 I observed workers from an MCC partner organisation deliver packets of instant noodles into a neighborhood mosque for the purposes of relief, and for a brief few minutes I helped carry them.

16 This is a long-standing phrase associated with MCC's work. Unruh's (1952) early history of MCC is entitled In the Name of Christ, though the motto's association with MCC pre-dated his usage.

17 See particularly Striffler's (2005) Chicken, a gritty and critical account of poultry production in the US. 
18 In 2005 the mobile meat canner was under threat of being shut down in Canada due to tightening regulations over concerns about BSE (White 2005). The MCC meat canner narrowly escaped being shut down by shifting meat production to turkey. The implicit fear of food inspectors is apparent in the conversion narrative of one Martin Rahn published in Canadian Mennonite (Nyce 2010). A CFIA employee, Rahn was initially suspicious of the mobile meat canner. However, after inspecting the work Rahn became a staunch supporter: 'Today, Rahn is one of several local food industry regulators who give annually of their time before, during and after the April arrival of the meat canner in Rahn's own hometown of Leamington, Ont.'

19 This contrasts sharply with the off cuts of fatty mutton flaps that Gewertz and Errington (2010) trace as they move from New Zealand and Australia to the Pacific. This, frozen rather than canned, journey is driven by cultural logics of distaste as much as anything else, as the mutton flaps tend to be regarded by affluent antipodean consumers as unappealing and unhealthy (they generally contain less than 50 percent lean meat).

20 Writing for the Chambersburg Public Opinion, (the aptly named) T.W. Burger (2013) quotes Glenn Showalter, a 74 year old local organiser, as stating that the canning operation at the Cumberland Valley Relief Center was divine in origin: 'God caused it to happen, not me.'

21 'Mennonite Urban Professional', see Lesher's droll The Muppie Manual (1985).

22 As noted earlier, canned meat did not circulate in Java at the time of my research and had not done so for decades. As a consequence my primary fieldwork site in Indonesia provided limited opportunities to trace the movements of canned meat in Indonesia. Moreover, as a consequence of a limited documentation trail on the reception of canned meat (especially vis-à-vis its highly textualised and frequently narrated production), my sources for these narratives are restricted almost entirely to interviews and field notes.

23 The devastating tsunami resulted in an estimated 130,000 to 170,000 fatalities in Aceh along and with over 500,000 displaced.

24 Dhabh therefore involves a theological investment in the manner in which animals are killed in a way in which Mennonite theologies of canning turkey did not. As discussed above, the practices of canning for Mennonite volunteers were sacramental and the killing was largely left to industrialised processes that took place elsewhere. 
25 That is, a non-Mennonite denomination.

26 See also Fountain (2013) for a similar, if parallel, provocation for reimagining the research agenda on 'religious NGOs.'

\section{REFERENCES}

Appadurai, Arjun, ed. 1988a. The Social Life of Things: Commodities in Cultural Perspective. Cambridge: Cambridge University Press.

- 1988b. 'Introduction: Commodities and the Politics of Value.' In The Social Life of Things: Commodities in Cultural Perspective, edited by Arjun Appadurai, 3-63. Cambridge: Cambridge University Press.

—.2006. 'The Thing Itself.' Public Culture 18 (1):15-21.

Asad, Talal. 1993. Genealogies of Religion: Discipline and Reasons of Power in Christianity and Islam. Baltimore and London: Johns Hopkins University Press.

- 2003. Formations of the Secular: Christianity, Islam, Modernity. Stanford, CA: Stanford University Press.

Bautista, Julius and Anthony Reid. 2012. 'Introduction: Materiality in a Problematically Plural Southeast Asia.' In The Spirit of Things: Materiality and Religious Diversity in Southeast Asia, Studies on Southeast Asia 58, edited by Julius Bautista, 1-10. Ithaca, NY: Southeast Asia Program, Cornell University.

Benthall, Jonathan and Jerome Bellion-Jourdan. 2009. The Charitable Crescent: Politics of Aid in the Muslim World. London: I. B. Tauris.

Bornstein, Erica. 2003. The Spirit of Development: Protestant NGOs, Morality, and Economics in Zimbabwe. New York: Routledge.

—. 2012. Disquieting Gifts: Humanitarianism in New Delhi. Stanford, CA: Stanford University Press.

Braun, Will. 2005. 'Buckets, Blankets and the WTO.' Canadian Mennonite, December 19. http://www.mcc.org/economicglobalization/viewpoints/perspectives/buckets.html.

Burger, Terry W. 2013. '500 Volunteers Canning 45,000 Pounds of Turkey 
for World's Hungry' http://www.publicopiniononline.com/latestnews/ ci_22724075/500-volunteers-canning-45-0oo-pounds-turkey-worlds.

Burkholder, John Richard. 2010. 'Leitourgia: Beyond Altar and Sacrifice: How Then Shall We Worship/serve God?' In Prophetic Peacemaking: Selected Writings of J.R. Burkholder, Scottdale, edited by Keith Graber Miller, 373-394. PA: Herald Press.

Busch, Jane. 1981. 'An Introduction to the Tin Can.' Historical Archaeology 15 (1):95-104.

Bush, Perry. 1998. Two Kingdoms, Two Loyalties: Mennonite Pacifism in Modern America. Baltimore and London: The Johns Hopkins University Press.

Cavanaugh, William. 2009. The Myth of Religious Violence: Secular Ideology and the Roots of Modern Conflict. Oxford: Oxford University Press.

Clifford, James. 1997. Routes: Travel and Translation in the Late Twentieth Century. Cambridge, MA and London: Harvard University Press.

Cronin, Michael. 200o. Across the Lines: Travel, Language, Translation. Cork: Cork University Press.

Cullather, Nick. 2010. The Hungry World: America's Cold War Battle Against Poverty in Asia. Boston: Harvard University Press.

Driedger, Leo and Don B. Kraybill. 1994. Mennonite Peacemaking: From Quietism to Activism. Scottdale, PA and Waterloo, Ontario: Herald Press.

Dula, Peter and Alain Epp Weaver, eds. 2007. Borders and Bridges: Mennonite Witness in a Religiously Diverse World. Telford, PA: Cascadia.

Dyck, Cornelius J., ed. 1980a. From the Files of MCC. Vol. 1. The Mennonite Central Committee Story. Scottdale, PA: Herald Press.

— Committee Story. Scottdale, PA: Herald Press.

Dyck, Peter and Elfrieda Dyck. 1991. Up from the Rubble. Scottdale, PA: Herald Press. 
Ekbladh, David. 2010. The Great American Mission: Modernization and the Construction of an American World Order. Princeton, New Jersey: Princeton University Press.

Ellen, Roy and Simon Platten. 2011. 'The Social Life of Seeds: The Role of Networks of Relationships in the Dispersal and Cultural Selection of Plant Germplasm. Journal of the Royal Anthropological Institute 17 (3):563-584.

Epp, Esther R. 1980. 'The Origins of Mennonite Central Committee (Canada)'. Unpublished Master of Arts Thesis, Winnipeg: University of Manitoba.

Epp, Frank H. 1974. Mennonites in Canada, 1786-1920: The History of a Separate People. Vol. 1. Mennonites in Canada. Toronto: Macmillan.

—, ed. 1983. Partners in Service: The Story of the Mennonite Central Committee Canada 1963-1982. Winnipeg: Mennonite Central Committee Canada.

Epp Weaver, Alain, ed. 2011. A Table of Sharing: Mennonite Central Committee and the Expanding Networks of Mennonite Identity. Telford, PA: Cascadia Publishing House.

Epp-Tiessen, Esther. 2011. 'New Wine for New Wineskins: MCC and the Formation of MCC Canada, in A Table of Sharing: Mennonite Central Committee and the Expanding Networks of Mennonite Identity, edited by Alain. Epp Weaver, 41-65. Telford, PA: Cascadia Publishing House.

Errington, Frederick, Tatsuro Fujikura and Deborah Gewertz. 2013. The Noodle Narratives: The Global Rise of an Industrial Food into the Twenty-First Century. Berkeley, California: University of California Press.

Escobar, Arturo. 1995. Encountering Development: The Making and Unmaking of the Third World. Princeton, NJ: Princeton University Press.

Ferguson, James. 1999. Expectations of Modernity: Myths and Meanings of Urban Life on the Zambian Copperbelt. Berkeley, CA: University of California Press.

Fischer, Johan. 2011. The Halal Frontier: Muslim Consumers in a Globalized Market. New York: Palgrave Macmillan.

Fisher, William F. 1997. 'Doing Good? The Politics and Antipolitics of NGO Politics.' Annual Review of Anthropology 26: 439-464. 
Fountain, Philip.2011. 'Translating Service: An Ethnography of the Mennonite Central Committee'. Unpublished Doctoral Dissertation, Canberra: Australian National University.

—.2013. 'The Myth of Religious NGOs: Development Studies and the Return of Religion.' International Development Policy: Religion and Development 4:9-30.

Geoghegan, Tom. 2013. 'The Story of How the Tin Can Nearly Wasn't'. BBC, April 21. http://www.bbc.co.uk/news/magazine-21689069.

Gewertz, Deborah and Frederick Errington. 2010. Cheap Meat: Flap Food Nations in the Pacific Islands. Berkeley and Los Angeles: University of California Press.

Gomart, Émilie and Antoine Hennion. 1999. 'A Sociology of Attachment: Music Amateurs, Drug Users.' In Actor-Network Theory and After, edited by John Law and John Hassard, 220-247. Oxford: Blackwell.

Graber Miller, Keith. 1996. Wise as Serpents, Innocent as Doves: American Mennonites Engage Washington. Knoxville, TN: University of Tennessee Press.

Gupta, Akhil. 2012. Red Tape: Bureaucracy, Structural Violence, and Poverty in India. Durham, NC: Duke University Press.

Gusterson, Hugh. 1997. 'Studying Up Revisited.' PoLAR: Political and Legal Anthropology Review, 20 (1):114-119.

Hefferan, Tara. 2007. Twinning Faith and Development: Catholic Parish Partnering in the US and Haiti. Bloomfield, CT: Kumarian Press.

Henare, Amiria, Martin Holbraad and Sari Wastell, eds. 2007a. Thinking Through Things: Theorising Artefacts Ethnographically. London \& New York: Routledge.

—. 2007b. 'Introduction: Thinking Through Things.' In Thinking Through Things: Theorising Artefacts Ethnographically, edited by Amiria. Henare, Martin Holbraad and Sari Wastell, 1-32. London \& New York: Routledge.

Hershberger, Guy F. 1970. 'Historical Background to the Formation of the Mennonite Central Committee. The Mennonite Quarterly Review 44 (3):213-244. 
Hilhorst, Dorothea. 2003. The Real World of NGOs: Discourses, Diversity and Development. London and New York: Zed Books.

Huang, C. Julia. 2009. Charisma and Compassion: Cheng Yen and the Buddhist Tzu Chi Movement. Cambridge, MA: Harvard University Press.

Hull, Matthew S. 2012. Government of Paper: The Materiality of Bureaucracy in Urban Pakistan. Berkeley and Los Angeles: University of California Press.

Jantzi, Terrence L. 20oo. 'Local Program Theories and Social Captial: A Case Study of a Non-Governmental Organization in Eastern Bolivia.' Unpublished Doctoral Dissertation, Cornell University.

Jones, Ben and Marie Juul Petersen. 2011. 'Instrumental, Narrow, Normative? Reviewing Recent Work on Religion and Development.' Third World Quarterly 32 (7):1291-1306.

Juhnke, James C. 1996. 'War and the Mennonite Agenda in the 2oth Century.' In Unity Amidst Diversity: Mennonite Central Committee at 75, edited by Robert Kreider, and Ron J. R. Mathies, 11-18. Akron, PA: Mennonite Central Committee.

- 2011. 'Turning Points, Broken Ice, and Glaubensgenossen: What Happened at Prairie Street on July 27-28, 1920?' In A Table of Sharing: Mennonite Central Committee and the Expanding Networks of Mennonite Identity, edited by Alain Epp Weaver, 66-83. Telford, PA: Cascadia Publishing House.

Jurgelski, Susan. 2010. 'Mennonite Central Committee Goes Mobile with Meat'. LancasterOnline.com, April 12, sec. Lifestyle. Retrieved from http://articles. lancasteronline.com/local/4/251015

Keane, Webb. 2004. 'Signs Are Not the Garb of Meaning: On the Social Analysis of Material Things.' In Materiality, edited by Daniel Miller, 182-205. Durham, NC: Duke University Press.

Kehler, Larry. 1970. 'The Many Activities of the Mennonite Central Committee.' The Mennonite Quarterly Review 44 (3): 298-315.

Kniss, Fred. 1997. Disquiet in the Land: Cultural Conflict in American Mennonite Communities. New Brunswick, NJ: Rutgers University Press. 
Kopytoff, Igor. 1986. 'The Cultural Biography of Things: Commoditization as Process.' In The Social Life of Things: Commodities in Cultural Perspective, edited by Arjun Appadurai, 64-91. Cambridge: Cambridge University Press.

Korf, Benedikt, Shahul Hasbullah, Pia Hollenbach and Bart Klem. 2010. 'The Gift of Disaster: The Commodification of Good Intentions in Post-tsunami Sri Lanka.' Disasters 34 (s1): S6o-S77.

Kreider, Robert S. and Rachel Waltner Goossen. 1988. Hungry, Thirsty, a Stranger: The MCC Experience. Scottdale, PA: Herald Press.

Kreider, Robert S. and Ron J.R. Mathies, eds. 1996. Unity Amidst Diversity: Mennonite Central Committee at 75: MCC and the 2oth Century North American Mennonite Experience. Akron, PA: Mennonite Central Committee.

Latour, Bruno. 1996. Aramis, or, The Love of Technology. Translated by Catherine Porter. Cambridge, MA: Harvard University Press.

- 1999. Pandora's Hope: Essays on the Reality of Science Studies. Cambridge, MA: Harvard University Press.

-2005. Reassembling the Social: An Introduction to Actor-Network-Theory. Oxford: Oxford University Press.

Lesher, Emerson L. 1985. The Muppie Manual: The Mennonite Urban Professional's Handbook for Humility and Success. Intercourse, PA: Good Books.

Lévi-Strauss, Claude. 1966. 'The Culinary Triangle.' In Food and Culture: A Reader, edited by Carole Counihan and Penny Van Esterik, 28-35. London: Routledge.

Lewis, David and David Mosse, eds. 2006. Development Brokers and Translators: The Ethnography of Aid and Agencies. Bloomfield, CT: Kumarian Press.

Loewen, Royden. 2008. 'The Poetics of Peoplehood: Ethnicity and Religion Among Canada's Mennonites.' In Christianity and Ethnicity in Canada, edited by Paul Bramadat and David Seljak, 330-364. Toronto: University of Toronto Press.

Lyon, Sarah. 2011. Coffee and Community: Maya Farmers and Fair-Trade Markets. Boulder, Colorado: University Press of Colorado. 
MacMaster, Richard K. 1985. Land, Piety, Peoplehood: The Establishment of Mennonite Communities in America, 1683-179o. Scottdale, PA: Herald Press.

Marcus, George E. 1995. 'Ethnography In/of the World System: The Emergence of Multi-Sited Ethnography'. Annual Review of Anthropology 24:95-117.

Marr, Lucille. 2003. The Transforming Power of a Century: Mennonite Central Committee and Its Evolution in Ontario. Kitchener, Ontario: Pandora Press.

- 2005. 'The History of Mennonite Central Committee: Developing a Genre.' Journal of Mennonite Studies 23:47-58.

Mennonite Central Committee. nd Meat Canning. Mennonite Central Committee. 13 September 2010. Retrieved from http://canning.mcc.org/

—. 2007a.'Taming Hunger: Part 1: Manna from Heaven.' DVD. Mennonite Central Committee.

—. 2007b. 'MCC | Sixty Early Years of MCC Meat Canning.' Mennonite Central Committee. May 27. Retrieved from http://canning.mcc.org/news/news/ article.html?id=185

Meyer, Birgit and Dick Houtman. 2012. 'Introduction: Material Religion - How Things Matter.' In Things: Religion and the Question of Materiality, edited by Birgit Meyer and Dick Houtman, 1-23. New York: Fordham University Press.

Miller, Daniel, ed. 2005a. Materiality. Durham, NC: Duke University Press.

—, ed. 2005b. 'Materiality: An Introduction.' In Materiality, 1-50. Durham, NC: Duke University Press.

Mosse, David. 2005, Cultivating Development: An Ethnography of Aid Policy and Practice. London: Pluto Press.

- 2013. 'The Anthropology of International Development.' Annual Review of Anthropology 42 (1):227-246.

Nadeau, Kathleen M. 2002. Liberation Theology in the Philippines: Faith in a Revolution. Westport, Connecticut \& London: Praeger.

Nolt, Steve. 1999. 'A Two-Kingdom People in a World of Multiple Identities: Reli- 
gion, Ethnicity and American Mennonites.' The Mennonite Quarterly Review $73(3): 485-502$.

Nyce, Ed. 2010. 'Meat Canning "Won't Work”' Canadian Mennonite. Retrieved from http://www.canadianmennonite.org/articles/meat-canning-wontwork

Occhipinti, Laura A. 2005. Acting on Faith: Religious Development Organizations in Northwestern Argentina. Lanham: Lexington Books.

Olivier de Sardan, Jean-Pierre. 2005. Anthropology and Development: Understanding Contemporary Social Change. London and New York: Zed Books.

Ortner, Sherry B. 1995. 'Resistance and the Problem of Ethnographic Refusal.' Comparative Studies in Society and History 37 (01):173-193.

Redekop, Calvin W. 1980. Strangers Become Neighbors: Mennonite and Indigenous Relations in the Paraguayan Chaco. Scottdale, PA \& Waterloo, Ont.: Herald Press.

Redfield, Peter. 2013. Life in Crisis: The Ethical Journey of Doctors Without Borders. Berkeley and Los Angeles, CA: University of California Press.

Regehr, Theodore D. 1991. 'Anatomy of a Mennonite Miracle: The Berlin Rescue of 30-31 January 1947. Journal of Mennonite Studies 9 (1):11-33.

Reimer, William and Bruce N. Guenther. 2011. 'Relationships, Rights, and 'Relief': Ninety Years of MCC's Integrated Response to Humanitarian Crises.' In A Table of Sharing: Mennonite Central Committee and the Expanding Networks of Mennonite Identity, edited by Alain Epp Weaver, 353-374. Telford, PA: Cascadia Publishing House.

Relief Canning, Inc. 2013. 'History of Relief Canning.' http://www.reliefcanningkidron.org/History.html.

Riles, Annelise. 200o. The Network Inside Out. Ann Arbor: University of Michigan Press.

—, ed. 2006a. Documents: Artifacts of Modern Knowledge. Ann Arbor: University of Michigan Press. 
- 2006b. 'Introduction: In Response.' In Documents: Artifacts of Modern Knowledge, edited by A. Riles, 1-38. Ann Arbor: University of Michigan Press.

Rist, Gilbert. 2002. The History of Development: From Western Origins to Global Faith (2nd ed). London: Zed Books.

Rothman, E. Natalie. 2011. Brokering Empire: Trans-Imperial Subjects Between Venice and Istanbul. Ithaca, NY: Cornell University Press.

Rottenburg, Richard. 2009. Far-Fetched Facts: A Parable of Development Aid. Translated by Allison Brown and Tom Lampert. Cambridge, MA: MIT Press.

Rudnyckyj, Daromir. 2010. Spiritual Economies: Islam, Globalization, and the Afterlife of Development. Ithaca, NY: Cornell University Press.

Sampson, Cynthia and John Paul Lederach, eds. 200o. From the Ground Up: Mennonite Contributions to International Peacebuilding. Oxford \& New York: Oxford University Press.

Shephard, Sue. 2006. Pickled, Potted, and Canned: How the Art and Science of Food Preserving Changed the World. New York: Simon \& Schuster Paperbacks.

Smith, James K. A. 2009. Desiring the Kingdom: Worship, Worldview, and Cultural Formation. Grand Rapids, MI: Baker Academic.

—. 2013. Imagining the Kingdom: How Worship Works. Grand Rapids, MI: Baker Academic.

Smucker, Barbara Claassen. 2006. Henry's Red Sea. Scottdale, PA and Waterloo, Ont.: Herald Press.

Taves, Ann and Courtney Bender. 2012. 'Introduction: Things of Value.' In What Matters? Ethnographies of Value in a Not So Secular Age, edited by Courtney Bender and Ann Taves, 1-33. New York: Columbia University Press.

Thomas, Nicholas. 1991. Entangled Objects: Exchange, Material Culture, and Colonialism in the Pacific. Harvard University Press.

Toews, Paul. 1996. Mennonites in American Society, 1930-1970: Modernity and the Persistence of Religious Community. Scottdale, PA: Herald Press. 
Tsing, Anna. 2005. Friction: An Ethnography of Global Connection. Princeton, NJ: Princeton University Press.

Unruh, John D. 1952. In the Name of Christ: A History of the Mennonite Central Committee. Scottdale, PA: Herald Press.

Urry, James. 2006. Mennonites, Politics, and Peoplehood: Europe-Russia-Canada: 1525 to 1980. Winnipeg, Manitoba: University of Manitoba Press.

Van Braght, Thieleman J. 2002. The Bloody Theater or Martyrs Mirror of the Defenseless Christians: Who Baptized Only Upon Confession of Faith, and Who Suffered and Died for the Testimony of Jesus, Their Saviour, From the Time of Christ to the Year A.D. 166o. Translated by Joseph F. Sohm. Scottdale, PA: Herald Press.

Van der Veer, Peter. 2001. Imperial Encounters: Religion and Modernity in India and Britain. Princeton: Princeton University Press.

Ver Beek, Kurt Alan. 200o. 'Spirituality: A Development Taboo.' Development in Practice 10 (1):31-43.

Vialles, Noélie. 1994. Animal to Edible. Translated by J.A. Underwood. Cambridge: Cambridge University Press.

Welty, Emily. 2010. 'Faith-based Peacebuilding and Development: An Analysis of the Mennonite Central Committee in Uganda and Kenya.' Unpublished Doctoral Dissertation, London: School of Oriental and African Studies.

West, Paige. 2012. From Modern Production to Imagined Primitive: The Social World of Coffee from Papua New Guinea. Durham, NC: Duke University Press.

White, Ed. 2005. 'BSE Threatens Mennonite Canning Work.' The Western Producer, April 14. http://www.producer.com/2005/04/bse-threatens-mennonite-canning-work/

Winland, Daphne N. 1993. 'The Quest for Mennonite Peoplehood: Ethno-Religious Identity and the Dilemma of Definitions.' Canadian Review of Sociology and Anthropology 30 (1):110-138.

Yoder, Richard A., Calvin W. Redekop and Vernon E. Jantzi. 2004. Development to 
SITES: New Series · Vol 11 No $1 \cdot 2014$

a Different Drummer: Anabaptist/Mennonite Experiences and Perspectives. Intercourse, PA: Good Books.

Yoder, Wanda L. 2010. Together We Can ... Our Seven-Month Journey with the MCC Mobile Meat Canner, 2008-2009. Morgantown, PA: Masthof Press. 